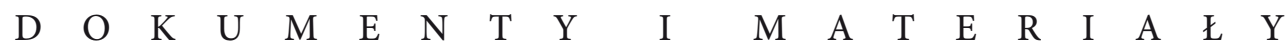

Studia z Dziejów Rosji i Europy Środkowo-Wschodniej XLVII PL ISSN 1230-5057

MAREK WOJNAR

\title{
ZACHÓD I STEP W DZIEJACH RUSI I ROSJI - DUALIZM CYWILIZACYJNY W PISARSTWIE HISTORYCZNYM LWA GUMILOWA
}

Urodzony w rodzinie słynnych poetów Anny Achmatowej i Nikołaja Gumilowa Lew Gumilow zasłynął w nauce jako twórca nowatorskiej koncepcji historiozoficznej określanej jako teoria etnogenezy. Oryginalność i kontrowersyjność przyjętej przez rosyjskiego badacza metodologii sprawiła, że cała naukowa spuścizna Gumilowa tak za jego życia, jak i po śmierci interpretowana była poprzez jej pryzmat. Kalectwo to dotyczyło również polskiej nauki. Spośród badań dotykających spuścizny „ostatniego eurazjaty” jedynie temat „teorii etnogenezy” można uznać za rzetelnie zbadany. Dokonał tego Ryszard Paradowski w opublikowanej w 1996 roku pracy Idea Rosji Eurazji i naukowy nacjonalizm Lwa Gumilowa, która po uzupełnieniu o rozdziały poświęcone twórczości Aleksandra Dugina ukazała się w 2001 roku pod tytułem Eurazjatyckie imperium Rosji - studium idei $i^{1}$. Inne, bardzo ciekawe z punktu widzenia historii konserwatywnej myśli rosyjskiej czy myśli historycznej (w szerszym tego słowa znaczeniu) fragmenty spuścizny Gumilowa stanowią w dalszym ciągu białe karty na mapie polskiej nauki². Dzieje się tak nawet pomimo ukazania się bądź też złożenia do druku kilku prac poświęconych problemom myśli Lwa Gumilowa. Niedawno wydaną książkę Małgorzaty Zuber Wpływ koncepcji euroazjatyzmu na pisarstwo historyczne Lwa Gumilowa ${ }^{3}$ zupełnie dyskwalifikuje materiał bibliograficzny pomijający bardziej obszerne źródła w języku rosyjskim. Inna, przygotowana obecnie do druku rozprawa Bartosza Gołąbka Lew Gumilow i Aleksander Dugin. O dwóch obliczach eurazjatyzmu w Rosji po 1991 roku, choć w wielu aspektach uzupełniająca naszą wiedzę o Gumilo-

1 Zob. R. Paradowski, Eurazjatyckie imperium Rosji - studium idei, Toruń 2001.

2 Pomijam tutaj rozdział z wyżej wymienionej pracy Paradowskiego napisany niemal wyłącznie na podstawie artykułu L. Gumilowa pt. Меня называют евразийцем, zob. ibidem, s. 196-214.

${ }^{3}$ Zob. M. Zuber, Wpływ koncepcji euroazjatyzmu na pisarstwo historyczne Lwa Gumilowa, Będzin 2008. 
wie $^{4}$ także nie stawia sobie za cel bardziej kompleksowego przedstawienia zagadnień myśli historycznej w pismach „ostatniego eurazjaty”. Zadanie omówienia wątków historiozoficznych i historycznych w pismach Gumilowa należy uznać za szczególnie ważne z uwagi na znaczenie jego postaci w dziejach myśli rosyjskiej.

Wśród rosyjskich filozofów Gumilowa można umieścić w grupie zwolenników nurtu antyokcydentalistycznego, który został w zapoczątkowany w pierwszej połowie XIX w. przez słowianofilów głoszących konieczność niepoddawania się wpływom europejskim i powrotu do ideału słowiańskiej soborowości ${ }^{5}$. Rosyjski konserwatyzm doczekał się w drugiej połowie XIX w. wielkich syntez historiozoficznych autorstwa Mikołaja Danilewskiego i Konstantego Leontjewa, z których dzieł wiele lat później czerpał Gumilow. Bezpośrednimi poprzednikami Gumilowa byli jednak myśliciele ruchu eurazjatyckiego, który został zapoczątkowany w 1920 r. wśród rosyjskiej emigracji w Sofii. Ruch ten stanowił tak uzupełnienie, jak i częściowe zaprzeczenie zasad słowianofilstwa. Przy absolutnie negatywnym stosunku wobec Europy Zachodniej i jej dziedzictwa eurazjaci odrzucili pogląd o słowiańskim charakterze cywilizacji rosyjskiej, przeciwstawiając jej koncepcję Rosji-Eurazji jako odrębnej cywilizacjí.

Wśród współczesnych Gumilowowi rosyjskich myślicieli konserwatywnych zdecydowanie największe znaczenie miał Aleksander Sołżenicyn. Porównanie Gumilowa z Sołżenicynem można określić mianem konfrontacji neoeurazjaty z neosłowianofilem. Gumilow bowiem szuka korzeni cywilizacyjnych Rosji w przestrzeni cywilizacyjnej Eurazji, podczas gdy Sołżenicyn nawiązuje do tradycji prawosławnego imperium w duchu słowianofilskim. Obydwu myślicieli łączy negatywny stosunek wobec Europy Zachodniej, dostrzeganie zagrożenia ze strony Chin oraz przekonanie, że komunizm stanowi dla państwa rosyjskiego formację obcą. Dla Sołżenicyna jednakże krytyka Zachodu sprowadzała się do sprzeciwu wobec laicyzacji tamtejszej cywilizacji rozpoczętej w czasach Odrodzenia i nawiązującego do niego Oświecenia, podczas gdy w pismach Gumilowa trudno znaleźć fragmenty mówiące w jakikolwiek sposób pozytywnie o superetnosie zachodnioeuropejskim ${ }^{7}$. Z tego stanowiska Sołżenicyna wynika stosunkowo pozytywna ocena katolicyzmu oraz katolickiej Polski, która w żaden sposób nie jest podzielana przez Gumilowa ${ }^{8}$.

Ze względu na szczupłość formy niniejszego opracowania poniższy artykuł sygnalizuje wyłącznie pewne problemy myśli historycznej Lwa Gumilowa. W polskiej literaturze póki co brakuje rzetelnego opracowania życiorysu Lwa Gumilowa, biorę

${ }^{4}$ Zob. B. Gołąbek, „Lew Gumilow i Aleksander Dugin. O dwóch obliczach eurazjatyzmu w Rosji po 1991 roku”, opracowanie w rękopisie.

${ }^{5}$ A. Walicki, Rosyjska filozofia i myśl społeczna od oświecenia do marksizmu, Warszawa 1973, s. $162-63$.

${ }^{6}$ I. Massaka, Eurazjatyzm: z dziejów rosyjskiego misjonizmu, Wrocław 2001, s. 55.

${ }^{7}$ L. Suchanek, Aleksander Sołżenicyn. Pisarz i publicysta, Kraków 1994, s. 102-103.

8 P. Głuszkowski, Antyrosja. Historyczne wizje Aleksandra Sołżenicyna. Próba polskiego odczytania, Warszawa 2008, s. 151-152. 
więc na siebie również obowiązek skrótowego przybliżenia czytelnikowi postaci „ostatniego eurazjaty”.

\section{Per aspera ad astra}

Lew Nikolajewicz Gumilow urodził się 1 października 1912 r. Pierwsze lata swojego niemal osiemdziesięcioletniego życia (zmarł 15 czerwca 1992 r.) spędził pod opieką babki najpierw w rodzinnym majątku Gumilowów, we wsi Slepniewo, a po przewrocie bolszewickim w pobliskim prowincjonalnym miasteczku Bieżeck. Matka Gumilowa - Achmatowa - ostatecznie rozstała się z synem, gdy ten liczył sześć lat, dając się wcześniej poznać jako beztroska matka. Nikołaj Gumilow oskarżony o udział w kontrrewolucyjnym spisku został rozstrzelany w $1921 \mathrm{roku}^{9}$. Pomimo trudnej sytuacji rodzinnej i niesprzyjających warunków nauczania ${ }^{10}$ młody Gumilow od najmłodszych lat przejawiał szerokie zainteresowania. Pierwszym impulsem pobudzającym jego wyobraźnię stała się literatura znajdująca się w bibliotece w Bieżecku ${ }^{11}$. Kolejnym krokiem było zamiłowanie historią poprzez lekturę starych podręczników z początków $\mathrm{XX}$ wieku. Po latach Gumilow te naukowe spotkania oceniał następująco: $B$ начале ХХ в. гимназическая история ограничивалась Древним Востоком, античной и средневековой Европойи Россией, причем изложение сводилось к перечислению событий в хронологической последовательности. Китай, Индия, Африка, доколумбова Америка и, главное, Великая степь Евразийского континента были тогда Terra incognita. Они требовали изучения ${ }^{12}$. Z historii, fascynacji odległymi cywilizacjami i dalekimi podróżami młody Gumilow czerpał inspirację dla innej swojej młodzieńczej pasji - poezji ${ }^{13}$.

W 1929 roku Gumilow zakończył bieżeckie gimnazjum i przeprowadził się do Sankt Petersburga. Pochodzenie miało zamknąć mu drogę na studia, skutkiem czego - jak sam później wspominał - jeździłem z ekspedycjami archeologicznymi i geologicznymi po całym kraju. Potem znalazłem się Tadżykistanie, pomagałem zwalczać komary malaryjne. Sam zapadłem na malarię, za to nauczyłem sie perskiego ${ }^{14}$. Zdobyte doświadczenia otworzyły Gumilowowi drogę do pracy w Instytucie Geologii, jednakże wybrał on studia historyczne.

Rok podjęcia studiów przez Gumilowa zbiegł się z zabójstwem Kirowa i powolnym umacnianiem stalinowskiego terroru, w obliczu czego "reakcyjne” pochodzenie okazało się piętnem. Syn Achmatowej po raz pierwszy trafił do aresztu na kilka dni

9 B. Gołąbek, op. cit.

${ }^{10}$ Szkoła lat dwudziestych pozbawiona była historii i zawierała minimalną liczbę godzin geografii, Ibidem.

${ }^{11}$ Młody Gumilow czytał m.in. Juliusza Verne’a, Jacka Londona, Herberta George’a Wellsa, Jamesa Coopera, Henry'ego Maine’a, Л. Гумилев, Биография научной теории или автонекролог, «Знамя». 1988. No 4, s. 202-216 <http://gumilevica.kulichki.net/articles/Article11.htm> [dostęp: 15 V 2011].

12 Ibidem.

13 B. Gołąbek, op. cit.

${ }^{14}$ L. Gumilow, My chodzimy własnymi drogami, [w:] A. Żebrowska, Portrety z Arbatu, Rzeszów 1991, s. 176. 
już w 1933 r. Po raz drugi Gumilow został uwięziony dwa lata później. Niedługo po uwolnieniu w 1938 r. na jednym z wykładów młody Gumilow wdał się obronę dobrego imienia swojego ojca, skutkiem czego został skazany na karę śmierci. Z anulowanym wyrokiem trafiał kolejno na budowę Biełomorkanału przez petersburskie więzienie Kriosty aż po kopalnie Norylska ${ }^{15}$. Przedwojenny okres obozowy przyniósł wiele interesujących obserwacji, które - jak się później okazało - miały przyczynić się do sformułowania teorii etnogenezy. Jak wspominał w latach dziewięćdziesiątych: $M$ Мıсль o пассионарности пришла в 1939 году, когда я находился в Крестах. Там раздумья о научных проблемах были предпочтительнее мыслей о личных обстоятельствах. Луч света проходил сквозь маленькое окошко и падал на цементный пол. Свет проникал даже в тюрьму. Значит, подумал я, и в истории движение происходит благодаря какой-то форме энергии ${ }^{16}$. Uznanie, że teoria pasjonarności została sformułowana w ciemnej celi leningradzkiego więzienia, nie wytrzymuje krytyki. Niemniej wiele wskazuje, że opisywane przez Gumilowa doświadczenie stanowiło coś w rodzaju - używając jego własnej terminologii - impulsu pasjonarnego. Również doświadczenie великих строек коммунизма miało wpływ na ukształtowanie się koncepcji różnorodności etnicznej. Opisując rzeczywistość obozową, Gumilow zauważa: там же были и казахи, и корейцы и русские, и немцыь, и китайць, и латыши. Отличались ти они друг от друга? Еще как! И каждый помагал своим. И каждый в случае чего держал за своих ${ }^{17}$.

Po odbyciu wyroku w 1944 r. Lew Gumilow wziął udział w walkach w Prusach Wschodnich oraz w zdobywaniu Berlina. Wróciwszy po wojnie do Petersburga, w 1948 roku obronił rozprawę doktorską pod tytułem Политическая исстория первого тюркского каганата VI-VIII в. н.э. Już w następnym roku po raz kolejny został aresztowany, a następnie zsyłany do obozów pod Karagandą, w Mieżdurieczinskie i pod Omskiem. Podczas tego drugiego zesłania Gumilow znacznie podupadł na zdrowiu, lecz nie zaprzestał aktywnej działalności naukowej. Wydane później w latach sześćdziesiątych prace Хунну oraz Древние тюрки zostały napisane właśnie w czasie zesłania na podstawie materiałów, które przesyłała mu matka ${ }^{18}$. Nawet odwilż po śmierci Stalina nie zmieniła losu Gumilowa. Jak sam wspominał: zwalniano banderowców, własowców, bo odsiedzieli swoje a ze mna nie wiedzieli, co zrobić. Dopiero w roku 1956 zaczęto wypuszczać na polecenie Chruszczowa i wyszedłem ${ }^{19}$.

Zaraz po wyjściu z obozu Lew Gumilow nawiązał korespondencję z jednym z ideologów międzywojennego eurazjatyzmu Piotrem Sawickim, która trwała przez lata 1956-1968. Jej zwieńczenie stanowiło praskie spotkanie uczonych w 1960 roku.

15 B. Gołąbek, op. cit.

16 Л. Гумилев, Я не был одинок, «Ленинградская правда» 30.12.1990, <http:/gumilevica.kulichki. net/articles/Article19.htm> [dostęp: 15 V 2011].

${ }_{17}$ Idem, Никакой мистики, [w:] idem, Чтобы свеча не погасла. Сборник эссе, интервью, стихотворений, Москва 2003, s. 53.

18 B. Gołąbek, op. cit.

19 L. Gumilow, My chodzimy własnymi drogami, [w:] A. Żebrowska, Portrety, s. 180. 
Przez Sawickiego odbywała się również pośrednia wymiana listów z Gieorgijem Wiernadskim, która jednakże nigdy nie została szerzej rozwinięta ${ }^{20}$. Prowadzona korespondencja zostawiła ślad w spuściźnie „ostatniego eurazjaty”.

Opuszczenie obozu nie zakończyło życiowych trudności Gumilowa. Po powrocie do Leningradu historyk dalej znajdował się pod czujnym okiem władz sowieckich. Towarzyszył temu ostracyzm środowiska naukowego tak niechętnego teoriom „ostatniego eurazjaty”, jak i z rezerwą odnoszącego się do „przeklętego pochodzenia” badacza. Zwieńczeniem wykluczenia stało się nieprzyznanie Gumilowowi tytułu doktora habilitowanego (przedłożył pracę Этногенез ибиосфера земли) nauk geograficznych w 1976 roku. Nawet objęcie władzy przez Gorbaczowa i związany z tym początek pierestrojki (zwłaszcza jej nurt jawnościowy) nie zmienił stosunku władz wobec syna Achmatowej. Pisane przez Gumilowa supliki były ignorowane i dopiero zdecydowana interwencja historyka Dymitra Lichaczowa spowodowała zmianę sytuacji. Dopiero od roku 1988 prace Gumilowa powoli stawały się znane szerszemu ogółowi ${ }^{21}$.

\section{Etnogeneza}

Okoliczności wytwarzania nowych całości kulturowych i cywilizacyjnych Lwa Gumilowa skorelowane są ze wspomnianą już wyżej teorią etnogenezy, czyli procesem powstawania, rozwoju i zaniku etnosów. Okoliczności wytworzenia etnosu wiążą się ściśle z wyróżnionym przez Włodzimierza Wiernadskiego - i wyżej już wspomnianym - pojęciem energii żywej materii biosfery. Gumilow, precyzując klasyfikację Wiernadskiego, wyróżnia trzy typy energii zasilającej ziemską biosferę: energię słoneczną, podziemny rozpad promieniotwórczy oraz rozproszone wiązki energii $\mathrm{w}$ galaktyce ${ }^{22}$. Właśnie ten ostatni rodzaj energii, którego pęczki uderzają co jakiś czas w Ziemię pasami o długości 200-300 kilometrów jawi się rosyjskiemu uczonemu jako źródło mutacji, które określa mianem impulsu pasjonarnego. Skutkiem impulsu wytwarza się cecha określana przez Gumilowa mianem pasjonarności. Oznacza ona zdolność do podejmowania ponadnaturalnych, często nieracjonalnych i sprzecznych $z$ instynktem samozachowawczym zachowań skutkiem akumulacji nadmiaru energii biochemicznej z biosfery. Ładunek pasjonarny, który otrzymuje etnos jest jednorazowy i ulega wyczerpaniu wraz z upływem czasu. Wcześniej jednakże etnos przechodzi przez wiele faz, których długość jest w zasadzie jednakowa i wynosi - od momentu impulsu aż do całkowitego zaniku - 1500 lat. Pierwszą fazą etniczną jest tzw. zryw dzielący się na ukryty trwający 150 lat (określany też mianem fazy inkubacyjnej) oraz jawny. Skutkiem zrywu z rozmaitych grup etnicznych powstaje spojona energią pasjonarną jednolita całość - etnos. Wysoki stopień pasjonarności skłania ludzi do podejmowa-

${ }^{20}$ Wynikało to z obawy przed wysyłaniem korespondencji do USA, co w obliczu narastającej zimnej wojny mogło prowadzić do kolejnych kłopotów w życiu Gumilowa, B. Gołąbek, op. cit.

${ }^{21}$ Ibidem.

22 Л. Гумилев, Конеи, и вновь начало, Москва 1992, <http://gumilevica.kulichki.net/EAB/eab01. htmeab01chapter08> [dostęp: 15 V 2011]. 
nia ryzykownych działań ku podwyższonej ofiarności ${ }^{23}$. Kumulacja energii etnicznej następuje w fazie akmatycznej etnogenezy, co wszakże nie pobudza ludzi do tworzenia całości, lecz przeciwnie do niepodporządkowania się powszechnym regułom, liczenia się jedynie $\mathrm{z}$ własną naturą. Znajduje to wyraz $\mathrm{w}$ zmianie stereotypu zachowania, który zawiera się w wyrażeniu „bądź sobą”. Fazie tej towarzyszy silna wewnętrzna rywalizacja skutkująca chwilowym zahamowaniem procesu etnogenezy. Skutkiem walk ładunek pasjonarny etnosu maleje, a ludzie zabijają się nawzajem. Oznacza to wejście etnosu w fazę przełomu. Towarzyszy temu ogromny rozkwit kultury i sztuki, lecz nie świadczy to o wzroście poziomu pasjonarności, a przeciwnie - o jego obniżeniu. Okres ten kończy się zazwyczaj rozlewem krwi, skutkiem którego system odrzuca nadmiar pasjonarności, a w społeczeństwie ustala się ponownie pewna równowaga. Wówczas etnos zaczyna żyć siłą inercji - powstają wielkie państwa oraz ogromne zasoby materialne. Pasjonarność stopniowo maleje. Skutkiem jej zaniku dominującą pozycję w systemie zajmują subpasjonariusze ${ }^{24}$ - jednostki o obniżonej pasjonarności. Rozpoczyna się faza wsteczna, w której procesy rozkładu stają się nieodwracalne. $\mathrm{W}$ momencie gdy rozkład osiągnie wszystkie aspekty życia i nie pozostanie nic z bohaterskiej epoki, rozpoczyna się ostatnia faza - memorialna. Następnie zanika nawet pamięć i rozpoczyna się okres równowagi z przyrodą (homeostaza), który może być przerwany przez kolejny impuls ${ }^{25}$. Trzeba zaznaczyć, że od wyżej przedstawionych faz etnogenezy można wyszczególnić kilka wyjątków.

Wspomniana wyżej zależność występowania impulsów pasjonarnych od przejawów energii kosmicznej skutkowała niezbyt częstym wytwarzaniem grup etnicznych. Ryszard Paradowski podaje za Gumilowem, że autor wyróżnił dziewięć pasjonarnych wstrząsów ${ }^{26}$. Poznański historyk nie uwzględnił przy tym podczas analizy wywiadów

23 Ibidem.

${ }^{24}$ Używając precyzyjnych pojęć, Gumilow mianem subpasjonariusza określa osobę, u której siła instynktu samozachowawczego jest większa niż siła pasjonarności.

${ }^{25}$ L. Gumilow, Od Rusi do Rosji, Warszawa 1993, s. 12-15.

${ }^{26}$ Do XIII wieku Gumilow wymienia następujące wstrząsy. Pierwszy zaszedł w wieku XVIII p.n.e i powołał do życia Egipcjan, Hyksosów oraz Hetytów. Drugi miał miejsce w XI wieku p.n.e. i objął swym zasięgiem obszar od północnych Chin po Azję Centralną (Scytowie). W wyniku trzeciego (VIII w. p.n.e.) wytworzyły się etnosy starożytnych Rzymian, Sammitów, Etrusków, Gallów, Greków. Pojawiło się wówczas kilka nowych etnosów w południowo-wschodniej Azji oraz Persowie. Czwarty impuls przebiegł w III w. p.n.e i objął tereny na północ od Chin (od północnej Korei po Azję Centralną i Kazachstan). Powstały wówczas etnosy Sarmatów, Koreańczyków i Hunów. Po raz piąty Ziemia została napromieniowana dawką energii kosmicznej w I wieku n.e. Wówczas narodzili się Słowianie, Dakowie, Chrześcijanie (pisane z dużej litery, Gumilow bowiem zalicza ich do etnosów) oraz Żydzi. W VI wieku nastąpił kolejny wstrząs ważny szczególnie dla historii Arabów, Hindusów, drugiego rzutu Chińczyków i Japończyków. Impuls pasjonarny VIII wieku zrodził ludy europejskie: Hiszpanów, Niemców, Francuzów, Skandynawów. W wyniku ósmego wstrząsu do życia powołane zostały ludy Mongołów i Dżurdżenów. Dziewiąty wstrząs przebiegał w prostej linii od Litwy przez Turcję, aż po Etiopię, powodując powołanie do życia Litwinów, Turków Osmańskich oraz Wielkorusów. Wstrząs miał pewien przeskok, który zrodził Wielkorusów, co zaowocowało powstaniem Księstwa Moskiewskiego, Idem, Конеи и вновь, <http://gumilevica.kulichki. net/EAB/eab03.htm\#eab03chapter06> [dostęp: 15 V 2011]. 
z rosyjskim uczonym, które przekonują nas, że jego koncepcja uległa doprecyzowaniu. „Ostatni eurazjata” wyróżnił bowiem powstanie narodu amerykańskiego ${ }^{27}$, chociaż jego zdaniem wydzielił się on z większej, superetnicznej całości jako oddzielny etnos ${ }^{28}$. Trudno zresztą uznać to stanowisko za rażąco sprzeczne z rzeczywistością. Zupełnie inna sytuacja miała miejsce $\mathrm{w}$ końcu XVIII wieku, kiedy to na przestrzeni między Japonią, Chinami i Birmą aż po Afrykę Południową miał zajść ostatni w dziejach impuls pasjonarny ${ }^{29}$. Koncepcja pojawienia się powyższych etnosów nie została przez Gumilowa doprecyzowana, niemniej trzeba podkreślić jej istnienie.

Impuls pasjonarny przekazuje danemu etnosowi ładunek energetyczny, po czym jego rola się kończy. Oddziaływania determinujące kształt etnosu pochodzą już z regionów znacznie mu bliższych. Jak nas przekonuje Gumilow: Следовательно, неповторимое сочетание ландшабтов, в котором сложился тот или иной этнос, определяет его своеобразие - поведенческое и во многим даже културное ${ }^{30}$. Ale krajobraz otaczający etnos w nim zrodzony [podkr. M.W.] jest nie tylko czynnikiem, który konstytuuje jego kształt. Stanowi również jego ojczyznę (родина). Tak rozumiane pojęcie ojczyzny stanowi dla Gumilowa jeden z elementów koncepcji etnosu.

Wskutek dokonania powyższej interpretacji rosyjski uczony z wyraźną niechęcią odnosi się do grup ludzkich zmieniających swoje „nisze ekologiczne”. Znalazło to wyraz w opowieści Gumilowa o „udoskonaleniu” systemu nawadniającego Tygrysu i Eufratu przez Chaldejczyków. „Ostatni eurazjata” relacjonuje, iż Narbonid syn Nabuchodonozora przywiódł sobie z Egiptu żonę. Wraz z nią sprowadzono wielu egipskich inżynierów, którzy, owszem, świetnie znali system irygacyjny Nilu, lecz nie mieli pojęcia o specyfice Międzyrzecza. Efekty, jak można się domyślić, były tragiczne. Kilka stuleci później podobne niezrozumienie obcego krajobrazu wykazali Arabowie ${ }^{31}$. Gumilow popiera również swoją koncepcję przykładami z historii Gotów i Wandalów oraz kolonizacji prowadzonej przez Europejczyków. Krytyce pogląd Gumilowa poddaje Iwona Massaka, która stwierdziła, iż argumentacja rosyjskiego uczonego wypada blado wobec zniszczeń, jakie wyrządzili Eurazji „swoi”, czyli Józef Stalin,

27 В XVII веке англичане стали заселять Америку, и через полтораста лет возник новый этнос: американиы-янки, idem, Я не был одинок, <http://gumilevica.kulichki.net/articles/Article19. htm> [dostęp: 15 V 2011].

${ }^{28}$ Idem, Etnogeneza czyli o cyklicznym rozwoju ludzkości. Rozmowa z prof. Lwem N. Gumilowem, [w:] Zrozumieć świat: rozmowy z uczonymi radzieckimi, red. W. Osiatyński, Warszawa 1980, s. 317.

29 Przejawami tego impulsu, zdaniem Gumilowa, była modernizacja Japonii, a w Chinach najpierw powstanie Tajpingów, a następnie Kuomintangu. Tutaj zwraca uwagę fakt, iż początek reform okresu Meji nastąpił przed upływem 150 lat od wyróżnionego przez Gumilowa impulsu. Świadczyć to może o niedoprecyzowaniu koncepcji ostatnich wyszczególnionych przez Gumilowa impulsów, Л. Гумилев, История - наука естественная или визит к профессору Гумилеву, [w:] idem, Чтобы свеча, s. 30.

${ }^{30}$ Idem, Ритмы Евразии, [w:] idem, Ритмы Евразии. Эпохии и иивилизаиии, Москва 1993 s. 189.

31 Л. Гумилев, История - наука естественная или визит к профессору Гумилеву, [w:] idem, Чтобы свеча, s. 21. 
Nikita Chruszczow oraz Leonid Breżniew ${ }^{32}$. Osąd wyrażony przez łódzką badaczkę byłby zasadny, gdyby Gumilow rzeczywiście uznał przywódców komunistycznych za „swoich”. Tymczasem jak czytamy: Коммунисты изначально представляли собой специфический маргинальный субэтнос, комплектуемый выходиами из самых разных этносов. Роднило их всех не происхождение, а негативное, жизнеотрицающее мироощущение людей, сознательно порвавщих всякие связи со своим народом ${ }^{33}$. Ponieważ Gumilow w cytowanym wywiadzie wyszczególnia wśród komunistycznych przywódców Konstantina Czernienkę, powyższą opinię możemy odnieść nie tylko do inicjatorów spisku październikowego, lecz także do wszystkich późniejszych dygnitarzy WKP(b) i KPZR.

Czynnikami geograficznymi uwarunkowany jest również podział superetniczny. Gumilow proponuje niekonwencjonalny podział Ziemi na kontynenty, w którym morza nie dzielą, lecz łączą poszczególne obszary w jedną całość. Przykładem może być tu Morze Śródziemne spajające w przeszłości obszary superetnosu grecko-rzymskiego. Analogiczną rolę pełnią morza okalające Półwysep Indochiński. Znacznie częściej granice wyznaczają trudne do przebycia obszary lądów. Czasem przebiega ona w powietrzu: Europa Zachodnia oddzielona jest od Eurazji według ujemnej izotermy stycznia ${ }^{34}$. Gumilow wyróżnia kilka „kontynentów” stanowiących siedziby superetnosów: Europę Zachodnią, Eurazję, Bliski Wschód, Indie, Chiny ${ }^{35}$.

\section{Odwieczny wróg}

Myśl historyczna Lwa Gumilowa cechuje się przeciwstawieniem cywilizacyjnym Zachodu i Rosji. Jej źródeł należy poszukiwać w okresie Rusi Kijowskiej. Obraz Zachodu odmalowywany przez Gumilowa od początku jest zdecydowanie negatywny. Pierwszy raz z krytyką Europy spotykamy się przy okazji funkcjonowania państwa chazarskiego. Chazaria określana przez Gumilowa mianem chimery etnicznej ${ }^{36}$ bądź też antysystemu ${ }^{37}$ oceniana jest przez autora w sposób skrajnie negatywny. I właśnie

32 I. Massaka, op. cit., s. 162.

33 Л. Гумилев, В. Ермолаев, Горе от иллюзий, [w:] Л. Гумилев, Ритмы Евразии, s. 187.

${ }^{34}$ Warto zauważyć, że o ile sam Gumilow (L. Gumilow, Od Rusi, s. 19) twierdzi, iż izoterma stycznia przebiega przez Ukrainę i Białoruś do Morza Czarnego, podczas gdy Paradowski (R. Paradowski, Eurazjatyckie imperium, s. 12) widzi ją przebiegającą wzdłuż Łaby, czym rzekomo Gumilow miał usprawiedliwiać pojałtańskie granice ZSRS. Rzeczywisty przebieg izotermy stycznia nie pokrywa się z żadnym z tych opisów, Л. Гумилев, Ритмы Евразии, s. 189.

${ }^{35}$ Ibidem.

36 Форма контакта несовместных этносов разных суперэтнических систем, при которой исчезает их своеобразие. Выросшие в зоне контакты люди не принадлежат ни к одному из контактирующих суперэтносов, каждый из которых отличается оригинальными традициями и ментальностью. В химере же господствует бессистемное сочетание несовместных между собой поведенческих черт, на место одной ментальности приходит полный хаос изарящих в обществе вкусов взглядов и представлений, idem, Этносфера: история людей и история природь, Москва 2004, s. 561.

37 Системная иелостность тюдей с негативным мироощущением выработавшая общее для своих членов мировоззрение. Все антисистемнье идеологии и учения обединяются одной 
wśród sojuszników państwa chazarskiego „ostatni eurazjata” wymienia państwa Karolingów i Ottonów, określając je przy tym mianem imperialnych reżimów ${ }^{38}$. Bardziej złożoną krytykę Zachodu prezentuje Gumilow podczas omawiania okoliczności chrztu Rusi. Odmowę daną łacinnikom przez Włodzimierza wyrażoną słowami: Idźcie $z$ powrotem, gdyż ojcowie nasi nie przyjęli tego ${ }^{39}$ Gumilow łączy z sytuacją panującą w Rzymie w połowie X wieku. Gdyby papież był tylko myśliwym, graczem, kobieciarzem i pijanica, byłoby to jeszcze pót biedy. Ale biskup Rzymu wydawał uczty z obiadami na cześć dawnych bogów i pit zdrowie Szatana ${ }^{40}$ - pisze Gumilow i przekonuje, że wiadomości o tych bezeceństwach musiały docierać na Ruś. Misterne odtwarzanie tzw. łańcuchów wydarzeń ${ }^{41}$ (церочки событий), którą to metodę stosuje autor przy omawianiu dziejów Wielkiego Stepu, Gumilow nagle zamienia na bezkrytyczną wiarę w źródła. Dziwnym trafem dzieje się to wtedy, gdy sprawa dotyczy superetnosu zachodnioeuropejskiego. Bezeceństwa papieża to, zdaniem Gumilowa, tylko część spośród motywów, którymi kierował się Włodzimierz przy odmowie łacinnikom. Ich uzupełnienie stanowi dostrzegany przez Gumilowa rozwój antysystemów na Zachodzie oraz możliwość przeniesienia ich na Ruś. В обоих случаях они не могли спорить с теологами, изучивщими Коран и Библию, но они ощущали, что их хотят не просветить, а использовать. Таково свойство антисистемы - ее невозможно опровергнуть тогически, но она ощущаема, и каждый вправе ее не принять ${ }^{42}$. Gumilow nie wie, czy wśród misjonarzy zachodnich faktycznie znajdowali się przedstawiciele antysystemów. Sugestia jednak jest wyraźna i pośrednio dotyka całości cywilizacyjnej.

Potwierdzenie zarysowanej niechęci znajdujemy w narracji dotyczącej formowania się stronnictw na Rusi w pierwszej połowie XI wieku. Partia prozachodnia niezmiennie stanowi przedmiot krytyki Lwa Gumilowa. Pierwszym księciem reprezentującym jej interesy był, zdaniem rosyjskiego badacza, Światopełk I ${ }^{43}$. W późniejszych wiekach jej postulaty wyrażali m.in. Izasław oraz Światopełk $\mathrm{II}^{44}$. Wpływom okcydentalizmu, co ciekawe, czasami ulegała również Ławra Pieczerska ${ }^{45}$. Kierunek ten Gumilow ocenia

центральной установкой: они отрицают реальный мир его сложности и многообразии во имя тех или иных абстрактивных иелей, zob. ibidem, s. 518.

${ }^{38}$ Idem, Древняя Русь и Великая степь, Москва 2000, s. 111.

39 Ibidem, s. 55.

${ }^{40}$ Ibidem.

${ }^{41}$ Dla Gumilowa „łańcuchy wydarzeń” stanowią podstawę historii etnicznej: этническая история не беспорядочный набор сведений, „без начала и кониа” (А. Блок), и не просто „дней минувших анекдоты" (А. Пушкин), а строгие цепочки причинно-следственных связей, с началом и концом, переплетенные между собой, то, чтобы попасть в иель, надо учитывать прочлое процесса, его окружение в изучаемьй период и общую панораму после пятого акта трагедии. Да, именно трагедии, ибо каждый „конеи” - это гибель того, чему было посвящено историческое повествование, ibidem, s. 9.

42 Ibidem, s. 178.

${ }^{43}$ L. Gumilow, Od Rusi, s. 57.

${ }^{44}$ Idem, Древняя Русь и Великая, s. 115 і 201.

${ }^{45}$ Ibidem, s. 115. 
zdecydowanie negatywnie. Dzieje się tak dlatego, że - zdaniem naszego badacza Zachód, gdzie w IX wieku uformował się nowy agresywny superetnos, stanowił dla Rusi formację obcą ${ }^{46}$. Obcość warunkowała motywy postępowania z jego przedstawicielami. Opisując okoliczności wyprawy Bolesława Chrobrego na Kijów, Gumilow pisze bez specjalnego wzburzenia: cudzoziemskich wojów umieszczono $w$ domach kijowian i okolicznych wsiach. I natychmiast zaczęly się konflikty z miejscowa ludnością. Dosłownie w ciagu nocy wyrżnięto mnóstwo Polaków $w^{47}$. Postępowanie takie zapewne Gumilow usprawiedliwia grzechami „obcych”. Tych ostatnich jest kilka. Znajdziemy wśród nich uleganie negatywnym systemom ${ }^{48}$ oraz brak tolerancji religijnej ${ }^{49} \mathrm{czy}$ okrucieństwo $^{50}$. Chyba jednak najcięższym grzechem Zachodu jest przychylność wobec ciemiężycieli Chazarii - Żydów. Wspomniana już wyżej wspólnota interesów, jaka - zdaniem Gumilowa - funkcjonowała między Karolingami i Ottonami z jednej a wspólnotą żydowską z drugiej strony, opierała się na ekonomii, a w szczególności handlu niewolnikami pochodzącymi z krajów słowiańskich ${ }^{51}$. Nie jest więc przypadkiem, że gdy tylko rosyjski uczony dostrzega na Rusi zachodnie wpływy, to wraz z nimi pojawiają się Żydzi. Są w armii Światopełka I wracającego na Ruś, wspierają Izasława, aby wreszcie za czasów Światopełka II zyskać zdecydowany (choć chwilowy) wpływ na wydarzenia w państwie.

\section{Dziejowa alternatywa}

Wobec nieustającego cywilizacyjnego zagrożenia ze strony Zachodu i towarzyszących mu Żydów Ruś zmuszona była treści zdolnej zapewnić jej przetrwanie. Zdaniem Gumilowa poszukiwać można było jej tylko w dwóch ośrodkach cywilizacyjnych: w Bizancjum i Wielkim Stepie. Początków swoistej syntezy elementów stepowych i bizantyńskich możemy poszukiwać w pismach Gumilowa dotyczących okresu Rusi Kijowskiej. Bizancjum wkracza na arenę wypadków ruskich wraz z konwersją

46 Ibidem, s. 231.

${ }^{47}$ Uczciwie trzeba przyznać, że obrazów obojętności Gumilowa wobec agresywności i okrucieństwa przedstawicieli bliskich mu grup etnicznych nie ma zbyt wiele, nie ma bowiem specjalnie wielu przykładów takowego okrucieństwa, idem, Od Rusi, s. 59.

${ }^{48}$ Zdaniem Gumilowa cesarz Henryk IV na ciele swojej żony księżniczki kijowskiej Eupraksji odprawiał czarne nabożeństwa, co jak podkreśla bardzo imponowałoby księżniczkom burgundzkim czy włoskim. Eupraksja jednak uciekła od męża. Dla Gumilowa stanowi to dowód na inny stosunek, wobec sumienia na Rusi i na Zachodzie (czyli de facto brak sumienia u ludzi Zachodu). Kwestią dla nas zupełnie nieistotną jest fakt, czy Henryk faktycznie przynależał do sekty nikolaitów. Ważniejszy jest fakt, że Gumilow po raz kolejny przyjmuje informację negatywnie świadczącą o zachodnich Europejczykach, nie poddawszy jej żadnej krytyce. Również założenie o radości Burgundek czy Włoszek wobec obrzędów czarnej mszy odprawianej na ich ciele sformułowane jest a priori, ibidem, s. 74 .

${ }^{49}$ Według Gumilowa po zajęciu Halicza przez króla węgierskiego Kolomana wygnano biskupa, cerkwie zamieniono w kościoły, a ludzi zmuszono do przyjęcia katolicyzmu, idem, Древняя Русь и Великая, s. 236.

${ }^{50}$ Jednym z przykładów może być postępowanie Niemców wobec Słowian Połabskich, ibidem, s. 242 .

${ }^{51}$ Ibidem, s. 148-149. 
Włodzimierza. Oceniając chrzest, z cesarstwa Gumilow popada w panegiryczne tony, pisząc: Они остановили свой выбор на греческой ортодоксии, потому что в ней не было двойного дна. Византия хотела получить от Руси только дружбу и прекращение бессмысленных набегов на побережья Черного моря. И она не сдабривала проповедь православия хитросплетениями, пусть даже неумыиленными ${ }^{52}$. W podobnym duchu przebiega ocena grekofilskiego kierunku polityki Włodzimierza Monomacha ${ }^{53}$. Zarazem Gumilowowskie Bizancjum jest konstruktem dość powierzchownym, pozbawionym głębszych systematów, dość dalekim i w niewielki sposób oddziaływającym na sprawy ruskie. Cesarstwo jawi się autorowi jako nieblednące centrum kultury i religii. Mieszanka takich elementów sprawia, że Bizancjum może stanowić dla Rusi wyłącznie źródło kultury duchowej. Ogromny pozostały „kulturowy obszar” autor pozostawił do zagospodarowania, a następnie uczynił przy pomocy ludów Wielkiego Stepu.

Autor dokonał tego, zupełnie przewartościowując ocenę roli Połowców, Pieczyngów i Torków, a następnie Mongołów w ruskiej historii. Stanowi to jego najbardziej oryginalny wkład w skarbnicę myśli historycznej. „Ostatni eurazjata” zdecydowanie zerwał z koncepcją odwiecznej walki lasu ze stepem, uznając ją za ekstrapolację stosunków z XVIII wieku w daleką przeszłośćs ${ }^{54}$. Gumilow wskazywał przy tym na geograficzną jedność regionu. Zdaniem rosyjskiego badacza stosunki między Rusią a Połowcami opierały się przede wszystkim na intensywnej wymianie handlowej. Nie wykluczało to starć, niemniej jak przekonuje Gumilow: кочевое хозяйство не может существовать вне связи с земледельческим, потому что обмен продуктами одинаково важен для обеих сторон. Поэтому мы наблюдаем, наряду с военными столкновениями, постоянные примеры симбио ${ }^{55}$. Stosunki takie - przekonuje Gumilow - leżały $\mathrm{w}$ interesie obydwu stron. Połowcom nie opłacało się walczyć z Rusią, byli bowiem stroną zdecydowanie słabszą. Liczebność koczowników wynosiła kilkaset tysięcy, podczas gdy Rusinów było 5,5 miliona ${ }^{56}$. Przewadze liczebnej towarzyszyła, zdaniem Gumilowa, wyższość manewrowa. Zmieniające koczowiska plemiona Połowców, zmuszone poruszać się wozami, mogły w ciągu godziny pokonać maksymalnie cztery kilometry, co sprawiło, że były niemal bezbronne wobec ataków rosyjskiej konnicy ${ }^{57}$. Do tego rosyjski uczony dodaje nieumiejętność zdobywania twierdz przez ludy stepowe oraz przewagę w uzbrojeniu po stronie ruskiej ${ }^{58}$. Ale i Rusinom walki z Połowcami nastręczały niemało problemów. Unicestwienie przeciwnika, którego

52 Ibidem.

${ }^{53}$ L. Gumilow, Od Rusi, s. 56.

${ }^{54}$ Idem, Древняя Русь и ее соседи в системе международной торговли и натурального обмена, «Известия ВГО», т. 119, 1987, вып 3, s. 227-234, <http://gumilevica.kulichki.net/articles/Article63. htm> [dostęp: 15 V 2011].

${ }_{55}$ Idem, Древняя Русь и Кыпчакая Степь в 945-1225 г2, [w:] idem, Ритмы Евразии, s. 529.

${ }^{56}$ Idem, Древняя Русь и Великая, s. 323.

57 Idem, Древняя Русь и ее соседи, s. 227-234, <http://gumilevica.kulichki.net/articles/Article63. htm> [dostęp: $15 \mathrm{~V}$ 2011].

58 Idem, Древняя Русь и Великая, s. 216. 
koczowiska ciągnęły się od Dniestru do Irtysza, okazało się niemożliwe dla książąt ${ }^{59}$. Ostateczne przerwanie patowej sytuacji stało się realne dzięki polityce Włodzimierza Monomachia, który - zdaniem Gumilowa - zakończył bezsensowną wojnę $e^{60}$. Od tego czasu wzajemne stosunki miały przebiegać pokojowo. Dowodem tego jest, zdaniem Gumilowa, chociażby zapis latopisu ławrientiejskiego, zgodnie z którym w latach 1055-1236 miało miejsce 12 napadów Połowców na Ruś, tyleż najazdów Rusinów na Połowców, podczas gdy wzajemnych rusko-połowieckich operacji miało być aż trzydzieści. Udział koczowników w wewnętrznych walkach Rusi świadczy o wejściu Połowców w skład ziemi ruskiej czy też, używając terminów historii etnicznej, superetnosu ruskiego ${ }^{61}$. Analogicznie niemalże potoczyły się losy Torków.

Gumilow rozszerza pojęcie „Ziemi ruskiej” na koczowników. Ale nie tylko. Rosyjski uczony dokonuje tej operacji również w odniesieniu do ludów ugrofińskich. Jak przekonuje Gumilow: Русская земля включает угорские, финские, балтские (голядь) и тюркские племена, являвшиеся компонентами суперэтнической целостности ${ }^{62}$. Mało tego, również ruskie subetnosy (przekształcone następnie w etnosy), które wykształciły się w XII wieku, nie mają, zdaniem Gumilowa, w pełni słowiańskiego charakteru. Jak przekonuje nasz autor: Пусть суздальизы сложились из кривичей, мери и муромы, новгородиь - из кривичей, веси и словен, рязаниь - из вятичей и муромы, полочане - из кривичей.

Rola przypisana Połowcom i Torkom przez Gumilowa okazała się niebagatelna. Negując obraz walki Stepu i Lasu oraz zastępując go szkicem zgodnego współżycia koczowników i ludności osiadłej, „ostatni eurazjata” stworzył podstawy pod zanegowanie niszczycielskości najazdu Batu-Chana i przedstawienia okresu niewoli tatarskiej jako błogosławieństwa dziejowego dla Rusi. Ludy ugrofińskie w tym obrazie pełnią rolę wyłącznie uzupełniającą.

\section{Wiatry z Zachodu i Wschodu}

Myśl Lwa Gumilowa największe kontrowersje budzi na dwóch płaszczyznach. Pierwszą spośród nich jest teoria etnogenezy określana przez jego przeciwników mianem paranaukowej. Drugą dotyczącą ściśle historii - specyficzna ocena dziejów Rusi w okresie tzw. tatarskiego jarzma. Wiąże się ona z oceną samych Mongołów. Nie wdając się w szczegółowe omawianie dziejów państwa Czyngis-Chana, możemy skonstatować pozytywny stosunek Gumilowa wobec jego zasad prawnych wyrażonych w $\mathrm{Jasie}^{63}$ oraz

59 Ibidem, s. 217.

${ }^{60}$ Ibidem, s. 222.

${ }^{61}$ Ibidem, s. 222 i 251.

${ }^{62} \mathrm{~W}$ innym miejscu tej samej pracy Gumilow wyraża z kolei następującą opinię, zupełnie przecząc sam sobie. Русичам грозила худшая судьба: они перемешались с мерей, мордвой, муромой, яхвягами и куманами, так что их ожидало превращение в этническую химеру, а затем и аннигиляиия, ibidem, s. 370.

${ }^{63}$ L. Gumilow, Od Rusi, s. 95-96. 
przekonanie o nieszczególnie niszczycielskiej skali najazdów mongolskich w Azji ${ }^{64}$. Już wkrótce burza ze Wschodu dosięgnąć miała ziem ruskich, nad którymi równolegle zbierały się chmury z Zachodu. Którędy podążyła Ruś?

W pisarstwie historycznym Lwa Gumilowa poświęconym okresowi Rusi Kijowskiej odnajdujemy liczne wskazówki świadczące o wzrastającym wpływie Stepu na dzieje władztwa Rurykowiczów. Nie znajdują one wszakże wyłączności i nasz autor zauważa również wpływy bizantyńskie oraz łacińskie. Obraz ten uległ w wyniku Wielkiej Wyprawy Zachodniej całkowitemu przeobrażeniu. Względny pluralizm wpływów cywilizacyjnych został zastąpiony czystym dualizmem ${ }^{65}$. Decydujące znaczenie dla powyższej zmiany miały lata $1236-1252^{66}$.

Okres powyższy charakteryzował się równoległą ekspansją na ziemie ruskie dwóch światów - mongolskiego i zachodnioeuropejskiego. Wyprawie Batu-Chana towarzyszyło apogeum postępów Niemców i Szwedów w krajach nadbałtyckich. Dwa wiatry dziejowe stanowiące rzeczywiste procesy historii są przedmiotem specyficznej interpretacji Lwa Gumilowa.

Wschodni huragan przejawiający się zrównywaniem miast z ziemią ${ }^{67}$ stanowił dla Gumilowa coś w rodzaju letniej bryzy. Krytykę tradycyjnych opinii historiografii "ostatni eurazjata” rozpoczyna od zanegowania liczebności armii Batu-Chana ${ }^{68}$. Rosyjski uczony przekonuje, że plemię Mongołów liczyło w XIII wieku sześćset tysięcy ludzi, z czego na wojsko przypadało nie więcej niż 130-140 tysięcy ${ }^{69}$. Armia ta zmuszona była do walki na trzech frontach. W Chinach potykało się ok. 60 tysięcy wojowników, kolejne 40 tysięcy uwikłane było na froncie perskim. W rezultacie siły, jakie mógł rzucić Batu przeciw Rusi, nie przekraczały - zdaniem Gumilowa - 30-40 tysięcy ludzi ${ }^{70}$. W tym samym czasie rosyjski uczony liczebność ludności Rusi szacował na 11 milionów ${ }^{71}$. Stosunek sił stanowi przesłankę dla niemożliwości ustanowienia tatarskiego jarzma.

${ }^{64}$ Oceniając pozostawione przez muzułmańskich kronikarzy opisy zdobycia miast Chorasanu, podczas których Mongołowie mieli wycinać całe miasta w pień, Gumilow określa je mianem mitotwórstwa, które zrodziły „czarną legendę o bestialstwie Mongołów”, ibidem, s. 101-102.

${ }_{65}$ Mowa tutaj o tworzącej się granicy pomiędzy Litwą a Moskwą odpowiadającej granicy między superetnosem zachodnioeuropejskim a stepowym.

${ }^{66}$ Ewentualnie początkową datę można odsunąć do roku 1201, co związane jest z założeniem Rygi i początkiem ekspansji Zachodu nad Bałtykiem.

${ }_{67}$ Małe grody-twierdze zostaly przez ta lawine wprost zmiecione z powierzchni ziemi; Biełogorod, İesławiec, Borysow-Glebow znikły po tych wypadkach raz na zawsze z historii Rusi. W XIV wieku podróżnicy płynący w górę Donu widzieli na jego pagórkowatych brzegach tylko ruiny i pustkowia, tam gdzie jeszcze stosunkowo niedawno znajdowały się miasta $i$ wioski, B. Grekow, A. Jakubowski, Złota Orda i jej upadek, Warszawa 1953, s. 173.

${ }^{68}$ Przykładowo Romuald Wojna szacuje siły Batu na nieprzekraczające 150000 ludzi, R. Wojna, Wielki świat nomadów. Między Chinami i Europa, Warszawa 1983, s. 235.

69 Л. Гумилев, Древняя Русь и Великая, s. 410.

${ }^{70}$ Idem, Od Rusi, s. 111.

${ }^{71}$ Idem, Древняя Русь и Великая, s. 410. 
Oprócz braku możliwości nie było również chęci ku ustanowieniu zwierzchnictwa nad Rusią. Wielka Wyprawa Zachodnia w swoich celach miała mieć jedynie rozbicie Połowców, którzy - przyjmując do siebie wrogów Mongołów - Najmanów - wywołali konflikt trwający do 1240 roku. Stepowa wendetta wymagała doprowadzenia sprawy do końca. Wyprawa była w istocie wielkim rajdem kawaleryjskim ${ }^{72}$. Nic więc dziwnego, że rozbiwszy przeciwnika, Mongołowie nie wprowadzili podatków, nie pozostawili garnizonów ani też nie zawarli z książętami nierównoprawnych paktów ${ }^{73}$.

Z liczebności armii i celów dowództwa niejako automatycznie wypływa wniosek o stosunkowo niewielkim okrucieństwie wojny. I rzeczywiście; Gumilow hołduje temu poglądowi, przytaczając los Księstwa Włodzimierskiego, w którym w 1238 roku Mongołowie mieli spalić zaledwie czternaście miast z ogólnej liczby trzystu, a i te w następnym roku odbudowano ${ }^{74}$. Nasz autor używa również argumentacji niejako empirycznej opisując rajd Batu-Chana po ziemi ruskiej: Następnym na jego krwawym szlaku okazał się Kijów zamieniony w ruiny i zgliszcza... Ale zapewne zwiedzała pani Ławrę Peczerska i Sobór Sofijski $z$ XI wieku? $?^{75}$ - pyta „ostatni eurazjata” prowadzącą wywiad. Inne świątynie, które ocalały z okresu Rusi Kijowskiej, również stanowią dla Gumilowa dowód przeciw tezie o niszczycielskiej działalności Mongołów. Ciekawe, że podobnego argumentu „ostatni eurazjata” nie stosuje w odniesieniu do Kremla i Soboru Wasyla Błogosławionego, które przetrwały lata polskiej okupacji w XVII wieku" ${ }^{76}$. Nieliczne miasta, które faktycznie zostały zrujnowane, a ich ludność wymordowana, zawdzięczają ten los samym sobie. W stereotypie zachowania Mongołów znajdowało się bowiem przekonanie o nietykalności posłów. Władcy tych miast, którzy tego nie rozumieli i zdecydowali się na wymordowanie wysłanników, zdaniem Gumilowa, sprowadzili na siebie najazd. Archetypicznym wydaje się los zrównanego z ziemią Kozielska $^{77}$.

Niewątpliwy upadek Rusi Kijowskiej w XIII wieku jest obiektywnym faktem zazwyczaj wiązanym z najazdem. Gumilow ma na ten temat zupełnie inne zdanie. Rosyjski uczony całość upadku wiąże wyłącznie z historią etniczną, w obliczu której Ruś weszła $\mathrm{w}$ fazę wsteczną etnogenezy ${ }^{78}$. Podsumowując słowami rosyjskiego uczonego: cлedyem признать, что поход Батыя по маситабам произведенных разрушений сравним с междоусобной войной, обычной для того неспокойного времени ${ }^{79}$. Моżna więc zapytać, dlaczego pamięć, która pozostała po tych wydarzeniach, była zupełnie inna. Zdaniem Gumilowa winę za powstanie „czarnej legendy” Mongołów ponosi Zachód.

72 Idem, My chodzimy własnymi drogami, [w:] A. Żebrowska, Portrety, s. 177.

${ }_{73}$ Idem, Древняя Русь и Великая, s. 361.

${ }^{74}$ Ibidem, s. 314.

${ }^{75}$ Idem, My chodzimy własnymi drogami, [w:] A. Żebrowska, Portrety, s. 173.

76 Ibidem, s. 180.

77 Idem, Древняя Русь и Великая, s. 339.

78 Ibidem, s. 345.

${ }^{79}$ Ibidem, s. 350. 
Rosyjski uczony nie wskazuje jednoznacznie winnego, wymieniając to templariuszy ${ }^{80}$, to Zygmunta Herbersteina ${ }^{81}$. Antyokcydentalistyczny szlak ponownie kształtuje myśl autora Etnogenezy.

Zupełnie odmiennie „ostatni eurazjata” ocenia drugi wiatr dziejowy, który rozpętał się nad Rusią w XIII wieku. Ekspansja zakonów rycerskich nie stanowi dla Gumilowa wydarzenia wyrwanego z kontekstu ogólnodziejowego. Wręcz przeciwnie, „ostatni eurazjata” podkreśla ciągłość procesu: Натиск на восток, начавшисв в XI в., продолжался в XIII в., и в XIV в., когда были завоеваны литовиами Киев и Чернигов, и в XVII в., когда поляки сожгли Москву; в ХIX в. то же самое проделали $\oint$ раниузы и в ХХ в. хотели учинить немцы $\iota^{82}$. Podczas gdy wyprawa wojenna Batu-Chana jawi się jako pojedynczy epizod dziejowy, to ekspansja niemieckich rycerzy nad Bałtykiem stanowi kolejną odsłonę walki Rusinów, a następnie Rosjan (w każdym bądź razie prawosławnych) z „drapieżnym superetnosem zachodnioeuropejskim”. Nic dziwnego, że ta druga jest zdecydowanie niebezpieczniejsza. Gumilow nie pozostawia co do tego żadnych wątpliwości. Groza objawiała się w dwóch postaciach: Ludność ruska Niemcy traktowali jeszcze okrutniej niż Bałtów. Jeżeli, na przykład, pojmanych Estów czynili niewolnikami to Rusinów po prostu zabijali nie robią wyjątków nawet dla niemowląt ${ }^{83}$ - przekonuje rosyjski uczony. Gdy do tego absolutnie nieludzkiego obrazu dodamy przekonanie o tym, że tereny nadbałtyckie stanowiły bazę wypadową dla niewyczerpanych sił całego zachodnioeuropejskiego rycerstwa, można dostrzec powagę problemu odmalowanego przez Gumilowa ${ }^{84}$. Okrucieństwo stanęło w parze z ogromną potęgą. Czoła stawił mu książę nowogrodzki Aleksander Newski, który zatrzymał Szwedów w Finlandii i Niemców w Estonii. Niemniej zaraz potem Gumilow dodaje, że: zwycięstwo nie usunęło zagrożenia niemieckiej agresji, rycerze, bowiem mieli o wiele większe siły niż Nowogrodzianie ${ }^{85}$.

Prawdziwym tytułem wielkości księcia Aleksandra jest więc dla Gumilowa ostateczny ${ }^{86}$ wybór politycznej linii opartej na ścisłym sojuszu [podkr. M.W.] z Ordą. Do porozumienia mogło dojść, Batu-Chan potrzebował bowiem zabezpieczyć sobie tył w obliczu rozpoczynającego się „kurułtaju” w Karakorum. За помощъ, оказанную Батыю, он потребовал и получил помощь против немцев и германофилов ${ }^{87}$ - przekonuje Gumilow. Wsparcie wojskowe wkrótce miało zostać sformalizowane

80 Л. Гумилев, А. Куркчи, Черная легенда: историко-психологический этюд, 1989, N 1, s. 5-43. <http://gumilevica.kulichki.net/articles/bl04.htm\#para73> [dostęp: 15 V 2011].

81 Л. Гумилев, Всем нам Завещена Россия, [w:] idem, Чтобы свеча, s. 35.

82 Idem, Древняя Русь и Великая, s. 320.

${ }^{83}$ Idem, Od Rusi, s. 116.

84 Л. Гумилев, А. Панченко, Чтобы свеча не погасла. Диалог, Ленинград $1990<\mathrm{http} / /$ gumilevica. kulichki.net/TNEC/tnec02.htm> [dostęp: 15 V 2011].

${ }^{85}$ L. Gumilow, Od Rusi, s. 117.

${ }^{86}$ Wcześniej tę drogę przecierał ojciec Aleksandra Jarosław, który w 1243 roku miał zawrzeć z Batu układ sojuszniczy, idem, Древняя Русь и Великая, s. 419.

87 Л. Гумилев, А. Панченко, Чтобы свеча не погасла, <http://gumilevica.kulichki.net/TNEC/ tnec02.htm> [dostęp: 15 V 2011]. 
w postaci tzw. wychoda, który oznaczał: тот взнос, на который Орда содержала свое войско, помогавщее в войнах снемиами, титовцами и всеми врагами Великого княжества Владимирского ${ }^{88}$. W ten sposób Gumilow poszukuje i odnajduje ocalenie dziejowe Rosji na Wschodzie - w Eurazji.

Księciu Aleksandrowi, którego za bezprzykładne bohaterstwo w obronie ziemi ojczystej rosyjska Cerkiew prawosławna zaliczyła księcia w poczet świętych ${ }^{89}$ Gumilow przeciwstawia tzw. zapadników. Najwybitniejszym ich przedstawicielem jawi się naszemu autorowi Daniel Halicki. Zresztą wybitność nie jest tu odpowiednim słowem. Książę Halicza i Włodzimierza, zdaniem Gumilowa, żył cały czas złudzeniami o możliwości zjednoczenia Rusi. Pragnął w tym celu wykorzystać rycerzy, zjednoczyć siły wszystkich książąt i wypędzić Mongołów ${ }^{90}$. Program ten stanowiący linię okcydentalistów był zupełnie nierealny, gdyż papież i cesarz pragnęli wykorzystać Rusinów w walce z Mongołami, wykrwawić Ruś, a następnie ją sobie podporządkować. Superetnos zachodnioeuropejski po raz kolejny pokazuje twarz zbiorowości okrutnej. Tym razem brutalność dodatkowo podszyta jest podstępem.

Znajdująca się w rozsypce Ruś paradoksalnie w pewien sposób zaczęła się jednoczyć wokół dwóch obozów. Jeden spośród nich stanowili ludzi dawnej epoki, nierozumiejący zagrożeń epoki. Ich los miał się dopełnić wskutek ekspansji Litwinów. Drugi obóz składał się z ludzi nowej epoki skupionych wokół księcia Aleksandra, pojmujących żywotne interesy ziemi ruskiej. Ich działalność jawi się Gumilowowi jako przejaw nowego, jeszcze ukrytego zrywu etnogenezy ${ }^{91}$. Zajść on mógł dzięki kolejnemu dziewiątemu spośród wyróżnionych przez rosyjskiego badacza impulsów pasjonarnych. Zdaniem Gumilowa zaszedł on w początkach XIII wieku, a jego oś przebiegała od Pskowa do Brusy i dalej do Abisynii ${ }^{92}$. W jego wyniku na historyczną arenę miały wkroczyć dwa nowe pasjonarne etnosy: Wielkorusini i Litwini.

\section{Narodziny Rosji}

Stosunki moskiewsko-tatarskie Gumilow rozdziela na dwa okresy, których datą graniczną jawi się rok 1312, kiedy to chan Uzbek uczynił islam religią państwową. Okres do 1312 r. jest oceniany jednoznacznie pozytywnie. Gumilow pisze wręcz o symbiozie Moskwy i Tatarów. Świadczyć o niej, zdaniem rosyjskiego uczonego, może fakt, że po wybuchu walk wewnętrznych w Ordzie po śmierci chana Berke, kiedy istniała możliwość zerwania związków, książęta nie przestali jeździć do Saraju. Co więcej Smoleńsk

${ }^{88}$ Idem, Меня называют евразийцем, «Наш современник» 1991, No 1, s. $62-70$ <http://gumilevica. kulichki.net/articles/Article111.htm> [dostęp: 15 V 2011].

${ }^{89}$ Idem, Od Rusi, s. 119.

90 Ibidem, s. 122.

${ }^{91}$ W innym miejscu znowu Gumilow pisze, że Nowogród obroniły pasjonarne kresy fazy inercyjnej. Ta interpretacja pojawia się tylko raz, niemniej sygnalizujemy jej istnienie (Л. Гумилев, Древняя Русь и Великая, s. 354), Л. Гумилев, А. Панченко, Чтобы свеча не погасла, <http://gumilevica.kulichki. net/TNEC/tnec02.htm> [dostęp: $15 \mathrm{~V}$ 2011].

92 Л. Гумилев, Древняя Русь и Великая, s. 370. 
w obawie przed litewską agresją w 1274 miał wybrać dobrowolne podporządkowanie się Mongołom ${ }^{93}$. Kwestiom politycznym towarzyszy odmalowany z przekonaniem obraz codziennych stosunków pomiędzy Rusią a Mongołami. Gumilow pisze: Князья ездят в Сарай и гостят там, чтобы вернуться с раскосыми женами, в иерквах молятся за хана, смерды бросают своих господ и поступают в полки баскаков, искусные мастера едут в Каракорум и работают там за высокую плату, лихие пограничники вместе со степными батурами собираются в разбойничьи банды и грабят караваны ${ }^{94}$. Obraz odmalowany przez Gumilowa idealnie wpasowuje się $\mathrm{w}$ obecny w literaturze rosyjskiej romantyczny mit Orientu. Jego interpretacja dokonana przez naszego badacza sugeruje jednak, iż obraz „sielskiego Wschodu” wiąże się dla niego wyłącznie z Wielkim Stepem. Nie Kair i nie Bagdad, lecz Saraj i Karakorum okazują się punktami, z których bije światło.

Ocena wzajemnych stosunków Rusi Moskiewskiej i Złotej Ordy miała ulec zmianie w 1312 roku. Ustanowienie przez Uzbeka islamu jako religii panującej w Złotej Ordzie Gumilow interpretuje jako zerwanie ze stepowymi tradycjami i wejście w muzułmański superetnos ${ }^{95}$. Nie mogło budzić to zadowolenia rosyjskiego badacza, który konstatuje, że: Вместо этнического симбиоза появилось соглачение Орды с Москвой и жестокий нажим на Тверь и Рязань. Этот союз не был искренним. Обе сторонь не доверяли друг другу96. Zmiana akcentów naszego badacza w stosunku do Ordy nie oznaczała zupełnej redefinicji oceny. Mimo że identyfikacja świata Islamu z siłą groźną i okrutną występuje w pismach Gumilowa przekonanego o fanatyzmie islamskiej „,inkwizycji”" ${ }^{\prime 27}$, Orda nawet stanowiąca muzułmański sułtanat i etniczną chimerę ${ }^{98}$ w dalszym ciągu jawi się Gumilowowi jako coś znacznie lepszego od Zachodu ${ }^{99}$. Choć „ostatni eurazjata” przekonuje, że odmienność stereotypów zachowania uniemożliwia jakiekolwiek pozytywne kontakty między etnosami poszczególnych superetnosów, to nie można nie mieć wrażenia, że teoria ta niemal nie ma zastosowania $\mathrm{w}$ świecie muzułmańskim, a zupełnie w Bizancjum. Użycie reguły objawia się za to w pełni podczas stosunków Rosji z Zachodem oraz ludów stepowych z Chinami, co wszakże znacząco wykracza poza temat niniejszej pracy.

Negatywne przemiany dokonujące się w Ordzie w pierwszej połowie XIV w. miały, zdaniem Gumilowa, znaczny wpływ na kształtowanie się Rosji. Skutkiem przewrotu

93 Ibidem, s. 364-364.

94 Ibidem, s. 368.

95 Ibidem, s. 364.

${ }_{96} \mathrm{~W}$ innych swoich wypowiedziach Gumilow podkreśla, że nikt nie próbował nawracać Rusinów na islam, co świadczy o samodzielności ziemi zaleskiej oraz o tym, że stosunki moskiewsko-tatarskie w dalszym ciągu przypominały этнический симбиоз и союз двух крупных держав, нуждающихся друг в друге, а не покорение Руси Золотой Ордой. Idem, Меня называют евразийцем, <http://gumilevica. kulichki.net/articles/Article111.htm> [dostęp: 15 V 2011].

${ }_{97}$ Idem, Древняя Русь и Великая, s. 364.

98 Ibidem, s. 386.

99 Гораздо напряженнее был контакт с католиками. Его в полной мере ощутили западнье русские спустя два века, хотя и в коние XIV в. им было несладко. Ibidem, s. 388. 
Uzbeka Tatarzy niegodzący się na zmianę wyznania zaczęli masowo spływać na Zalesie. Gumilow podkreśla wagę tego, wyliczając wiele rodów szlacheckich pochodzących z mieszanych rusko-tatarskich małżeństw ${ }^{100}$. W ujęciu Gumilowa działo się tak ze względu na wprowadzoną przez Iwana Kalitę zasadę tolerancji etnicznej; w Moskwie wybór ludzi służyłych miał polegać tylko na przydatności ${ }^{101}$. Dzięki temu na Zalesie ściągać mieli nie tylko Tatarzy, lecz także prawosławni Litwini, ochrzczeni Połowcy, ugrofińscy Merowie, Mordwini i Muromcy. Jedynym warunkiem przyjęcia na służbę miał być chrzest w obrządku prawosławnym ${ }^{102}$. Wysoka pasjonarność etnosu miała umożliwiać przyjmowanie w swój skład przedstawicieli innych etnosów, co przyczyniało się do zwiększenia złożoności systemu ${ }^{103}$. „Ostatni eurazjata” przekonuje wszakże, że całej tej pstrokaciźnie przemieszanej z plemionami ruskimi do zlania się w jeden etnos brakowało jeszcze jednego - poczucia wspólnego losu historycznego ${ }^{104}$. Przewodnikiem w drodze do jego wypełnienia miała okazać się Cerkiew prawosławna.

Historyczny start Rusi Moskiewskiej uważa Gumilow za trudniejszy niż sąsiedniej Litwy. Wynikać to miało z innego punktu startowego: na Rusi impuls nałożył się na fazę wsteczną, wskutek czego subpasjonariusze mieli przeszkadzać ludziom energicznym. Miejscem schronienia dla tych ostatnich okazać się miały monastery. Właśnie tam oni: развернули такую деятельность, которая определила культурно-политическое развитие России более чем на 200 лет $^{105}$. Wzrostowi znaczenia Cerkwi sprzyjało umocnienie tradycji chrześcijańskich na Rusi Północno-Wschodniej ${ }^{106}$. Skutkiem tego na Rusi miało wykształcić się wysoce pasjonarne konsorcjum, którego program można określić mianem „prawosławnej teokracji”. Autor wymienia między innymi metropolitę Aleksego, a także Sergiusza Radoneżskiego, Dionizego Suzdalskiego i Fiodora Smoleńskiego. Gumilow nie precyzuje niestety dokładnie celów politycznych stronnictwa, niemniej zaznacza tendencje zjednoczeniowe i rolę wiary prawosławnej ${ }^{107}$.

Partia prawosławna stanęła na czele zjednoczenia. Właśnie to stronnictwo miało poprowadzić rozdrobnioną Ruś na Kulikowe Pole, gdzie określił się jej los dziejowy.

W obliczu zaistniałego konfliktu z wodzem Złotej Ordy Mamajem w Moskwie miał nastąpić podział. Priorytetem działań partii narodowej stała się Зaщ̧uma самостоятельности государственной, идеологической, бытовой и даже творческой означала войну с агрессией Запада [podkr. M.W.] и союзной с ней

100 Np. Aksakow, Bułłchakow, Czadajew, Karamzin, Tiutczew. Ibidem, s. 365.

101 Idem, Od Rusi, s. 136.

102 Митрополии служили тверичи, рязанцьь, смоляне, суздальцы, киевляне, белорусы, крещеные татары и крещеные зыряне, карель и ижоряне, новгородцы и псковичи. А Москве - только московиты, idem, Древняя Русь и Великая, s. 388.

103 Ibidem, s. 385.

104 Idem, Эпоха Куликовской битвы, «Огонек» 1980 N 35, s. 16-17 <http://gumilevica.kulichki. net/articles/Article47.htm> [dostęp: 15 V 2011].

105 Idem, Древняя Русь и Великая, s. 374.

${ }_{106}$ Idem, Od Rusi, s. 137.

107 Idem, Древняя Русь и Великая, s. 390. 
ордой Мамая ${ }^{108}$. Kierunkowi temu sprzeciwiali się subpasjonariusze skupieni wokół metropolity Mitaja. Naszkicowany przez Gumilowa obraz zawiera kilka elementów. Pierwszym spośród nich jest lojalizm Dymitra. Mamaj bowiem przedstawiony jest jako buntownik, podczas gdy książę moskiewski znajduje się w sojuszu z prawowitym chanem Tochtamyszem (co prawda nieobecnym na Kulikowym Polu). Tumennik wszakże nie jest do końca samodzielnym politykiem, Gumilow bowiem dostrzega za jego plecami kupców genueńskich, którym nie szczędzi bardzo krytycznej oceny ${ }^{109}$. Sama wojna, zdaniem rosyjskiego badacza, wybuchła na tle ich handlowych przywilejów. Gdy do powyższej oceny dodamy rzeczywisty sojusz Mamaja z Litwą, całkiem zrozumiałe staje się, dlaczego Gumilow jest przekonany, że na Kulikowym Polu Rusini stawiali czoła siłom Zachodu. Czy w takim razie Dymitr Doński reprezentował Wschód? Zważywszy na podkreślany przez Gumilowa lojalizm księcia i sojusz z prawowitym chanem, nie ma podstaw, aby odrzucać tę hipotezę. Dodatkową przesłanką potwierdzającą ten stan rzeczy jest obecność licznych Mongołów w armii Dymitra, którzy za czasów Uzbeka schronili się na Rusi i stali się trzonem moskiewskich zastępów, które rozgromiły Mamaja ${ }^{110}$. Na Kulikowym Polu, w ujęciu Gumilowa, Wschód i Zachód zmieniają się rolami, a Mamaj, który nie pasuje do tego obrazu, sprowadzony zostaje do roli nic nieznaczącego statysty. Gdy bitwa zostaje przegrana, nikomu niepotrzebny element $\mathrm{w}$ postaci przegranego wodza może być usunięty. Zabójstwo Mamaja w Kaffie Gumilow interpretuje jako dowód na posiadanie przez ludzi Zachodu innego stereotypu zachowania. Jak pisze „ostatni eurazjata”: У генуэзиев была иная этика. Они считали, что главное в жизни - выгода, что монголы и тюрки почти не люди, а объект для коммерческих операций. Когда они сильны, их надо использовать, когда ослабли -выкинуть. По сути это была психология зарождавщегося капитализма ${ }^{111}$. W ten sposób do obrazu Zachodu zostaje wkomponowany element ludobójczego kapitalizmu. Nie oznacza to bynajmniej przejścia z okrucieństwa fizycznego do bezwzględności finansowej. Ten pierwszy element również obecny jest na Kulikowym Polu. Gumilow znajduje bowiem miejsce w konflikcie dla spóźnionych Litwinów Jagiełły, którym przypisuje rolę siepaczy rannych z wojska Dymitrowego ${ }^{112}$. Co ważne większość wojska Jagiełły stanowili Rusini.

${ }^{108} \mathrm{~W}$ innym miejscu tego samego artykułu Gumilow sugeruje, że starcie z Mamajem oznaczało walkę na poziomie superetnicznym pomiędzy rodzącą się Rusią a światem islamu. Ocena ta nie przeczy wyżej zacytowanej, świat bowiem islamu raczej pełni tu rolę wykonawcy, co niżej postaram się wykazać, idem, Эпоха Куликовской битвы, s. 16-17, <http://gumilevica.kulichki.net/articles/Article47.htm> [dostęp: 15 V 2011].

109 Genueńczycy wznieśli twierdze na Krymie i rozpoczęli ożywiony handel najpierw na Powoł̇̇, a następnie także na Rusi rozciagając swoje wplywy aż do Wielkiego Ustiugu. Nic dobrego z tego dla miejscowej ludności nie wynikło: nie bez powodu Dante w swej Boskiej Komedii pisał, że najniższe kręgi piekła zajmuja Genueńczycy, wśród których są sami łotrzy, idem, Od Rusi, s. 139.

110 Idem, Dzieje etnosów Wielkiego Stepu, Kraków 1997, s. 93.

111 Idem, Древняя Русь и Великая, s. 391.

112 Idem, Меня назывют евразийцем, <http://gumilevica.kulichki.net/articles/Article111.htm> [dostęp: $15 \mathrm{~V}$ 2011]. 
Zwycięstwo na Kulikowym Polu miało, zdaniem Gumilowa, przełomowe znaczenie dla ukształtowania się etnosu rosyjskiego i Rusi Moskiewskiej. На Куликово поле вышли жители разных княжеств, а вернулись оттуда жителями единого Моссковского русского государства ${ }^{113}$ - przekonuje Gumilow. Poczucie wspólnego losu zaistniało, dzięki czemu różnorodna ludność Rusi Zaleskiej zlała się w jeden etnos. Kontakt na poziomie etnicznym i pasjonarny wzrost zostały uzupełnione o poczucie wspólnego losu historycznego. Droga była określona. Uchylić się od niej miał Nowogród ${ }^{114}$, a co ważniejsze Litwa.

\section{Litewski błąd}

Drugim etnosem Europy Wschodniej, który miał zostać powołany do życia impulsem pasjonarnym XIII w., byli Litwini. Pierwszym spośród ludzi nowego pokolenia w ujęciu Gumilowa był rówieśnik Aleksandra Newskiego - książę Mendog. Starożytne plemiona litewskie miały znajdować się w stanie homeostazy, skutkiem czego nowi pasjonariusze byli w stanie przekonać ogół ludności do swoich celów i wykorzystać ich naturalną waleczność w podbojach ${ }^{115}$. Wcześniej wszakże nastąpić miał charakterystyczny dla wczesnej fazy zrywu okres walk wewnętrznych, który został zakończony wraz z zwycięstwem Giedymina. Książę ten rozpoczął ekspansję Litwy. Zwraca uwagę stosunkowy pozytywny stosunek Gumilowa wobec tego władcy: Giedymin, człowiek madry i o silnej woli, mimo że sam był poganinem, potrafił się liczyć z chrześcijańską ruską ludnościq̨ ${ }^{116}$. Ocena ta odnosi się wyłącznie do Giedymina, rosyjski bowiem uczony zwraca uwagę, że charakterystyczna cecha czternastowiecznej Litwy było zachowanie wiary w pogańskiego Boga Peruna i bardzo zły stosunek do chrześcijan zarówno wschodnich jak $i$ zachodnich ${ }^{117}$. Negatywna ocena Litwy dodatkowo umocniona jest przekonaniem Gumilowa o pogromach wschodnich chrześcijan dokonywanych przez Olgierda (notabene władcę prawosławnego) ${ }^{118}$. Jeszcze bardziej umacnia ją ocena litewskich najazdów. Gumilow podkreśla, że: Летописи [podkr. M.W.] свидетельствуют, ито набеги литовцев, хотя и пеших, были намного более жестокими, нежели набеги татарских разбойников, которых было много, как во всякой стране в то время, но которых наказывали сами татарские ханы ${ }^{119}$. Z pasją rekonstruowane przez „ostatniego eurazjatę” „łańcuchy wydarzeń” odnoszące się do historii Mongołów po

${ }^{113}$ В какое время мы живем? (Диалог Льва Гумилева и Димитрия Балашова), idem, Чтобы свеча, s. 95.

114 Idem, Эпоха Куликовской битвы, s. 16-17 <http:/gumilevica.kulichki.net/articles/Article47. htm> [dostęp: $15 \mathrm{~V} 2011]$.

115 Idem, Древняя Русь и Великая, s. 379.

116 Idem, Od Rusi, s. 134.

117 Ibidem.

118 Gumilow uważa przyjęcie prawosławia przez Olgierda za wyłącznie koniunkturalne, ibidem, s. 135 i 147.

119 Idem, Меня называют евразийцем, <http://gumilevica.kulichki.net/articles/Article111.htm> [dostęp: 15 V 2011]. 
raz kolejny zostają zastąpione prostą wiarą w literę tekstu źródłowego, gdy przychodzi do oceny etnosu, który ostatecznie miał związać się z Zachodem.

Wzrost pasjonarności Litwy wymagał, zdaniem Gumilowa, wyboru nowej kultury konstytuującej dalszy rozwój ${ }^{120}$. Podboje Giedymina, a następnie Olgierda uczyniły z Litwy potężne państwo, w którym przeważającą część ludności stanowili prawosławni. $\mathrm{Z}$ drugiej wszakże strony Giedymin, aby zrównoważyć wpływy, miał dać zgodę na крещение Литвы в католичество ${ }^{121}$. Następсу wielkiego księcia: Olgierd i Kiejstut mieli rządzić w państwie z преимущественно русским населением и причудливой смесью западной и древнерусской культур ${ }^{122}$. Dłuższe trwanie takiego stanu - zgodnie z teorią Gumilowa - zapewne doprowadziłoby do powstania etnicznej chimery, tak więc trzeba było wybierać. Konieczność szybkiej decyzji dodatkowo Gumilow podkreśla epizodem oblężenia twierdzy Kowno przez Krzyżaków, kiedy to Giedymin i Kiejstut nie zdecydowali się na starcie ze znacznie lepiej uzbrojonymi rycerzami, wskutek czego zamek padł. Zdaniem „ostatniego eurazjaty” nawet tak wojowniczy etnos nie mógł egzystować bez przyjaciół ${ }^{123}$. Wybór był prosty: prawosławie czy katolicyzm.

Chrzest Władysława Jagiełły w obrządku katolickim „ostatni eurazjata” interpretuje negatywnie. Если бы литовцы сумели слиться с покоренным большинством культурного населения своего государства, то они стали бы великой державой. Но этому помешал сладкий соблазн - католическая Польша ${ }^{124}$ - przekonuje Gumilow. Myliłby się ktoś, jeżeli myślałby, że stracona szansa na zostanie wielkim prawosławnym państwem to wszystkie minusy, jakie „ostatni eurazjata” przywołuje na poparcie tezy o „litewskim błędzie”. Podwyższona pasjonarność miała wywołać zmiany w stereotypie zachowania Litwinów. Jego przykładem ma być postępowanie przywódcy okcydentalistów Jagiełły z Kiejstutem stojącym na czele prawosławnych. Wielki Książę zwabił swojego stryja na ucztę, a następnie zamordował, podczas gdy syn Kiejstuta Witold trafił do więzienia. Ale wzrost energii etnicznej prowadzić mógł też do innych rezultatów. Dziewczyna dostarczająca uwięzionemu w wieży Witoldowi jedzenie zdolna była poświęcić własne życie, aby ratować księcia. Ciekawe, że odpowiednie stereotypy zachowań przypisane są członkom poszczególnych partii - polonofilskiej i rusofilskiej. W obliczu tego w Krewie Litwa miała wybierać pomiędzy ofiarnością a okrucieństwem i zdradą ${ }^{125}$. W taki sposób Wschód i Zachód wkroczyły w dzieje Wielkiego Księstwa. Litwa wybrała Zachód, wskutek czego, wbrew kompromisowemu stanowisku księcia Witolda, miała nastąpić polaryzacja stanowisk religijnych. W efekcie pasjonarność litewską z racji usytuowania państwa pomiędzy Polską a Rusią Moskiewską odciągnęli sąsiedzi. Część Litwinów miała opowiedzieć się

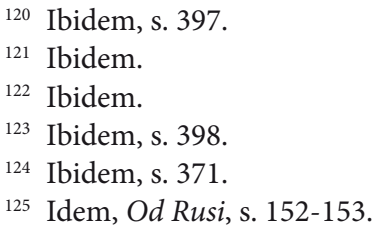


za prawosławiem, a część wybrać katolicyzm ${ }^{126}$. Czy podobnie stałoby się w wypadku triumfu prawosławia? Czy też Moskwa zachowałaby przewagę? Na te pytania Gumilow odpowiedzi nie udziela, pozostają nam więc domysły.

\section{Od Rusi do Rosji}

Przedstawienie bitwy na Kulikowym Polu jako obrony Rusi przed zakusami Zachodu stanowiło operację skomplikowaną. Mające miejsce dwa lata po tym wydarzeniu zdobycie Moskwy przez legalnego chana Złotej Ordy Tochtamysza w żaden sposób nie mogło zostać przedstawione podobnie. Rzeczywiście Gumilow zwraca uwagę, iż spalenie stolicy przez Tatarów spowodowało zmiany emocjonalne we wzajemnych stosunkach z Ordą. Władza chana jest jeszcze odbierana jako oczywistość, ale już zaczyna ciążyć, cała Ruś chce się od niej wyzwolić, tym bardziej że pod koniec XIV wieku sojusz z Orda nie przynosił już Moskwie dawnych korzyści $i^{127}$ - przekonuje Gumilow. Zarazem rosyjski badacz zwraca uwagę, że najazd Tochtamysza w istocie stanowił rezultat udanej prowokacji książąt suzdalskich, którzy zbałamucili człowieka nieznającego fałszu [Tochtamysza - przyp. M.W.] ${ }^{128}$. Przykład Tochtamysza ukazuje, że stosunek Gumilowa do władzy tatarskiej pod koniec XIV oraz w XV wieku uległ pewnej modyfikacji. Znowu nie jest to wszakże zmiana jakościowa. Już w następnym pokoleniu Szadibek ma bronić Moskwy przed litewskim naporem ${ }^{129}$. Kilkadziesiąt lat później Wasyl II miał najmować na służbę wielu wychodźców z Ordy, co - zdaniem Gumilowa - wzmocniło Moskwę, a osłabiło Tatarów ${ }^{130}$. Warto dodać, że podobnie tolerancyjna polityka stosowana była również wobec uchodźców z Wielkiego Księstwa Litewskiego, którzy w następstwie prozachodniej polityki Zbigniewa Oleśnickiego emigrowali na Zalesie ${ }^{131}$.

Słabnięcie i rozsypywanie się Ordy na niezależne chanaty sprawiało, że sojusz wojskowy nie gwarantował już Moskwie dawnych perspektyw. Zgodnie z tym stanowiskiem Gumilow interpretuje wydarzenia 1480 roku, które, jego zdaniem, były jedynie epizodem w długotrwałej walce dwóch koalicji: nowogrodzko-litewsko-ordyńskiej i moskiewsko-kasimowsko-krymskiej. Tym bardziej nie ma żadnych podstaw do twierdzenia, że „stanie nad Ugra” oznaczało zrzucenie jarzma tatarsko-mongolskiego. Jak widzimy z Orda praktycznie przestał się liczyć już ojciec Iwana III, Wasyl Ślepy, który włączał etniczne okruchy Złotej Ordy w skład swego wielkiego księstwa ${ }^{132}$ - przekonuje Gumilow. Właśnie włączony element tatarski miał odegrać ważną rolę w wojnie z Litwą na początku XVI w. Moskwa przeszła długą drogę w stosunkach z Ordą,

126 Ibidem, s. 135.

127 Ibidem, s. 156.

128 Ibidem, s. 153.

129 Ibidem, s. 164.

130 Idem, Древняя Русь и Великая, s. 464.

131 L. Gumilow, Rozmowa z Lwem Gumilowem, rozmawiał Zbigniew Pogorzec, „Tygodnik Powszechny", 11 VIII 1974, s. 8.

${ }^{132}$ Idem, Od Rusi, s. 178. 
lecz ich całokształt niemal zawsze prezentował się pozytywnie. Symbioza zmieniła się w pewnym momencie w sojusz wojenny, a gdy ten przestał być przydatny dla książąt, Moskwa wzmocniła się etnicznie kosztem rozpadającej się Tatarszczyzny, przejmując znaczną część jej treści. I gdy Złota Orda upadała w 1502 r. pod ciosami Mengli Gireja, to państwu następców Iwana z racji spuścizny pisane było odnowić imperium Czyngis-Chana.

Wcześniej wszakże Moskwie przyszło ostatecznie skończyć z odmiennymi staroruskimi tradycjami. Ostatnim ich bastionem na Rusi był, zdaniem Gumilowa, Nowogród Wielki. Kupiecka republika już w czasie Kulikowego Pola miała uchylić się od uczestnictwa w ogólnoruskiej sprawie. W końcu XV w. Nowogród wybierający sojusz z katolicką Litwą przez nikogo na Zalesiu nie był już uważany za „swoich”. Zwycięstwo Iwana ostatecznie przecinało staroruskie tradycje.

Podstawą ideologiczną dla dojrzewającego państwa stało się odrzucenie przez Wielkie Księstwo Moskiewskie unii florenckiej. Odmienny od Cesarstwa wybór Gumilow interpretuje jako opcję swoistej dominanty zachowania. Zachwianie odwiecznej zasady zależności od Konstantynopola w sprawach cerkiewnych podczas wyboru metropolity Jonasza „ostatni eurazjata” interpretuje jako przejaw wzrostu pasjonarności ponad poziom zapewniający jej istnienie jako etnosu. Ruś bowiem zaszła już daleko na drodze przekształcenia etnosów w superetnos. Ale zachwianie związku z patriarchatem można interpretować też inaczej tzn. jako powstanie swoistej, odmiennej od bizantyńskiej wersji prawosławia. Можно сказать, что в России возродилась... нет, не Византийская империя, а скорее мечта о изарстве пресвитера Иоанна, которую не смогли осуществить иентральноазиатские несториане ${ }^{133}$ - przekonuje Gumilow. Przestrzeń stepu wchłonęła w siebie złote kopuły prawosławnych soborów. Eurazjatycka droga Rosji była określona.

Okres Rusi Moskiewskiej jest dla Gumilowa decydujący. W tym czasie rozstrzygnąć się miał ostatecznie jej los. Część zachodnia, której ucieleśnieniem jest Wielkie Księstwo Litewskie, miała ostatecznie związać się z Zachodem, utwierdziwszy w ten sposób swoją niewolę. Odmiennie Zalesie - Moskwa stawała się najpierw sojusznikiem, a następnie sukcesorem świata mongolskiego. Wybór ten otwierał drogę do wielkości, którą oświetlał blask Cerkwi. Cała reszta była jego kontynuacją.

\section{Konsekwencje}

Dokonany przez Rosję wybór dziejowy określił jej dalszą drogę. Właśnie w tych kategoriach należy rozpatrywać kolonizację Syberii przez Rosję tzn. jako ponowne zjednoczenie eurazjatyckiej przestrzeni cywilizacyjnej. Opisy Gumilowa przedstawiające idylliczne stosunki ekspansji rosyjskiej, w których autor powołuje się na Dostojewskiego powiadającego, iż jeżeli Francuzów cechuje duma i umiłowanie piękna, Hiszpanów zazdrość, Anglików uczciwość i skrupulatność, Niemców pedan-

133 Idem, Древняя Русь и Великая, s. 464. 
teria to Rosjanie maja umiejętność rozumienia i akceptowania innych narodów ${ }^{134}$ jawią się nam jako podążanie po właściwej, eurazjatyckiej drodze. W podobnych kategoriach możemy interpretować rolę Rosji w powstaniu Chmielnickiego, choć tutaj dostrzegalny jest nie eurazjatycki, lecz antyzachodni (jako przeciwniczki Rzeczypospolitej) charakter tożsamości rosyjskiej. O wiele mocniej jest on zaznaczony przy ocenie europejskiej polityki Zofii i Piotra. „Ostatni eurazjata” określa polityczny zwrot dokonany przez carową mianem niepopularnego i niezrozumiałego. Co więcej oznaczać miał on odejście od zasad chrześcijańskiej ortodoksji [sic! - M.W.], gdyż okrutne traktowanie prawosławnych przez katolików nie dało się porównać z tym jak odnoszono się do bałkańskich chrześcijan w imperium osmańskim ${ }^{135}$. To ostatnie jest, zdaniem rosyjskiego badacza, znośne. Gumilow po raz kolejny daje upust swoim antyokcydentalistycznym emocjom, otwarcie przyznając, że Rosji bliżej nie tylko do sielskiego Wschodu stepowego, lecz także do despotycznego Wschodu muzułmańskiego aniżeli do Zachodu. Forma jakiegokolwiek sojuszu z tym ostatnim miała się okazać zgubna dla państwa carów. Fiasko wypraw Golicyna stanowi dla Gumilowa tylko potwierdzenie takiego stanu rzeczy. Podobnie oceniana jest przez „ostatniego eurazjatę" polityka Piotra, która choć zmieniła swój wektor w stosunku do polityki Zofii (poprzez wejście w sojusz z państwami protestanckimi), nie nabrała znamion samodzielności. Politycy europejscy postanowili wykorzystać Piotra przeciw Szwecji tak jak wcześniej wykorzystali Golicyna i Zofię w walce przeciw Turcji ${ }^{136}$ - pisze Gumilow i przekonuje, że im się to udało.

Szczególnie silny i zgubny wpływ zachodnich oddziaływań na rosyjską tożsamość nastąpił w XIX w., co miało być związane z obniżeniem pasjonarności. Оказалось, что западнические влияния, то, что А. Тойнби называл оксидентализаиией (от английского осcidentally — «на западный манер»), очень развились, что сысрало в нашей судьбе самую роковую роль ${ }^{137}$ - przekonuje Gumilow. Następujący po XIX wieku okres Związku Sowieckiego rozpatrywany jest przez Gumilowa odmiennie, niemniej komunizm, podobnie jak i okcydentalizm, zaprzecza eurazjatyckiej tożsamości Rosji. Według Gumilowa komuniści, którzy przechwycili w Rosji władzę w 1917 roku stanowią niewielki subetnos o negatywnym światopoglądzie ${ }^{138}$. W kontekście takiej oceny panowanie sowieckie należy uznać za coś w rodzaju choroby. Jego koniec związany z okresem pierestrojki oznacza dla „ostatniego eurazajaty” przejście z fazy przełomu do epoki inercyjnej. Autor mówi w trybie niedokonanym, dalszy bowiem żywot superetnosu eurazjatyckiego, dalsze istnienie Rosji jako oddzielnej cywilizacji

134 Idem, Od Rusi, s. 243.

135 Ibidem, s. 257.

${ }^{136}$ Ibidem, s. 262.

137 Idem, Меня называют евразийцем, <http://gumilevica.kulichki.net/articles/Article111.htm> [dostęp: 15 V 2011].

138 Pytanie o charakter elementów, które dokonały rewolucji bolszewickiej przed 14 laty postawił Ryszard Paradowski, nie znajdując wówczas odpowiedzi. Wydaje się, że powyższy wywiad z uczonym ją daje, Л. Гумилев, В. Ермолаев, Горе от иллюзий, [w:] Л. Гумилев, Ритмы Евразии, s. 188. 
zależy od jej wewnętrznej tożsamości. Lew Gumilow nie pozostawia żadnych wątpliwości, że Если Россия будет спасена то только как евразийская держава и только через евразийство ${ }^{139}$.

\section{Zakończenie}

Rzeczywisty dualizm cywilizacyjny dziejów Rusi i Rosji stworzony przez Lwa Gumilowa wyróżnia się na tle innych koncepcji ideologów rosyjskiego konserwatyzmu. „Ostatni eurazjata" poszedł w krytyce Zachodu i jego wpływów o wiele dalej niż większość jego poprzedników. Duchowy patron Gumilowa Konstanty Leontjew krytykował wyłącznie współczesną jemu burżuazyjną Europę, będąc pełnym podziwu dla dawnego świata katedr, zamków i rycerzy. W tym duchu wypowiadał się również Aleksander Sołżenicyn. Syn Achmatowej również w okresach katolickiej ortodoksji dostrzega w dziejach Zachodu ciągłe przejawy negatywnego myślenia, rozwoju antysystemów, ludobójstwa czy zdrady. Podobnie negatywny stosunek do Zachodu cechował Mikołaja Danilewskiego oraz myślicieli eurazjatyzmu międzywojennego. Od Danilewskiego odróżnia Gumilowa odrzucenie panslawizmu i wybór eurazjatyckiej tożsamości. Z kolei od eurazjatów - zaopatrzenie swojej teorii w potężny aparat naukowy (czy też może raczej pseudonaukowy). Lew Gumilow stworzył koncepcję fascynującą i porażającą ogromem elementów. Pozorny pluralizm cywilizacyjny myśli Gumilowa w rzeczywistości jest dualizmem. Już w okresie Rusi Kijowskiej zbudowane zostają podstawy pod wytworzenie cywilizacyjnego przeciwieństwa. Po jednej stronie ustawiony zostaje Zachód i wspierający go Żydzi stanowiący nieustanne zagrożenie dla państwowości kijowskiej, po drugiej Wielki Step i Bizancjum oddziaływające na Ruś jednakowo pozytywnie, lecz w innych aspektach ${ }^{140}$.

W kolejnej epoce przeciwieństwo to zostaje utwierdzone wpierw poprzez sojusz Batu-Chana z księciem Aleksandrem Newskim, a następnie litewską „zdradę”. Późniejszy okres stanowi kontynuację wyborów dokonanych na przestrzeni XIII-XIV w. Od samego przeciwieństwa bardziej zadziwiający jest jego charakter. Antytezą Zachodu nie jest bowiem Bizancjum ani Słowiańszczyzna, lecz cywilizacja Wielkiego Stepu. Dzieje stepowych nomadów stanowią dla Gumilowa opowieść o poświęceniu i bohaterstwie, co zdecydowanie odróżnia go od tradycyjnych narracji historiograficznych. Czy słusznie? Pamiętając o celach koczowników i uwzględniając ich kulturową odmienność, uważam, że w dalszym ciągu należy stawiać pytania o ocenę historii Wielkiego Stepu i związków mongolsko-ruskich dokonanych przez Gumilowa. Wątpliwości bowiem pozostają. Budzi je zwłaszcza nagminnie stosowana w odniesieniu do dziejów koczowników metoda tzw. łańcuchów wydarzeń, która przy opisie historii Zachodu zamieniana jest na bezkrytyczną wiarę w źródła. Na krytykę zasługują również rozmaite przeinaczenia

139 Idem, Скажу вам по секрету, что если Россия будет спасена то только как евразийская держава..., [w:] ibidem, s. 31.

140 Posługując się terminologią zaproponowaną przez XIX-wieczną szkołę niemiecką, można uznać, że Połowcy kształtowali cywilizacyjne oblicze Rusi, podczas gdy Bizancjum odpowiadało za aspekt kulturowy. 
własnej teorii, dzięki którym Ruś może zachowywać poprawne stosunki z superetnosem muzułmańskim, a nawet pozytywne z Bizancjum, podczas gdy teoria o wzajemnej wrogości na poziomie superetnicznym zawsze znajduje zastosowanie w odniesieniu do Zachodu. Taki sposób rozumowania powoduje, że Zachód i Wielki Step stają się synonimami odpowiednio unicestwienia i zbawienia. A w obliczu tak postawionej alternatywy, dziejowy wybór Rosji może być tylko jeden. 